\title{
Simple and robust DNA extraction method for the large-scale analysis of genotypes containing high polyphenolic content, such as landraces of Solanum tuberosum and Zea mays
}

\author{
Macarena Barra' ${ }^{1,2}$, Erika Salazar ${ }^{1,3}$, María Beltrán $^{4}$, and Boris Sagredo ${ }^{5}$ \\ ${ }^{1}$ Instituto de Investigaciones Agropecuarias, Centro Regional de Investigación La Platina. Casilla 439-3 \\ Correo Central, Santiago, Chile. \\ ${ }^{2}$ Universidad de La Frontera, Casilla 54-D, Temuco, Chile. \\ ${ }^{3}$ Facultad de Agronomía e Ingeniería Forestal, Pontificia Universidad Católica de Chile. Casilla 306, \\ Santiago, Chile. \\ ${ }^{4}$ Universidad de Concepción. Casilla 160-C. Concepción, Chile. \\ ${ }^{5}$ Instituto de Investigaciones Agropecuarias, Centro Regional de Investigación Rayentué. Casilla 13, Rengo, Chile.
}

\begin{abstract}
M. Barra, E. Salazar, M. Beltrán, and B. Sagredo. 2012. Simple and robust DNA extraction method for the large-scale analysis of genotypes containing high polyphenolic content, such as landraces of Solanum tuberosum and Zea mays. Cien Inv. Agr. 39(3): 593-601. The extraction of high-quality DNA is essential for studies conducted at the molecular level in species with an abundance of contaminants in their tissues, such as some landraces of potato and maize, in which it is difficult to extract good-quality genomic DNA. Compounds such as polyphenols interfere with the amplification of DNA during polymerase chain reaction (PCR), which makes it difficult to conduct PCR-based studies of molecular markers. This article describes a simple and robust protocol for DNA isolation that was applied to potato and maize landraces and resulted in a high DNA concentration with excellent purity and quality. This method is based on the method of Krizman et al. (2006) with some modifications and was tested on potato leaves and young maize leaves. The protocol was compared with one commercial DNA extraction kit and three methods that were previously described for plant DNA extraction: Keb-Llanes et al. (2002), for plants with high polyphenolic content; Fulton et al. (1995), which was developed for Solanaceae and other herbaceous plants; and the original Krizman et al. (2006) cetyltrimethylammonium bromide (CTAB)-activated charcoal method. The method proposed is suitable for isolating DNA from potato and maize genotypes with high polyphenol contents, yielding high-quality DNA that can be utilized for molecular techniques that involve PCR, cutting with restriction enzymes and other applications. The method is short, similar to a commercial kit, but cheaper. The amount of DNA extracted from maize using our method is superior compared with other published methods tested in this article.
\end{abstract}

Key words: Activated charcoal, DNA extraction, genomic DNA, polyphenols.

\section{Introduction}

Potato (Solanum tuberosum L.) and maize (Zea mays L.) are model species for genetic research (Mullins et al., 2006). Large-scale genetic diversity

Received January 9, 2012. Accepted May 31, 2012. Corresponding author: macarenabarrajimenez@gmail.com studies, high-resolution mapping and the mapbased cloning of genes are increasing in these species, and each of these procedures requires the isolation of high-quality DNA from a large number of plants. There are currently various DNA extraction procedures for species like maize and potato, but the ability to obtain highly pure DNA and ensure sufficient quantities is limited due 
to the high presence and diversity of secondary phenolic metabolites (phytochemicals), which are synthesized in response to adverse weather and local production conditions (Bennett and Wallsgrove, 1994). These secondary metabolites are generally abundant in potato plants native to southern Chile, forming part of the pigments of the leaves, flowers and tubers (Huamán and Spooner, 2002). Additionally, they are abundant in plants and grains from Andean populations of cereals and legumes (Ranilla et al., 2006; Ranilla et al., 2009). Although the distribution of these compounds depends on the type of vegetable tissue, they are frequently present in leaves, the most common tissue used to extract DNA (Boiteux et al., 1999). Such polyphenolic compounds have been reported as contaminating agents that present obstacles to DNA purification in other plant species, including the medicinal plants Sclerocarya birrea Hochst., Aloe polyphylla Schönland ex Pillans and Barleria greenii M. Balkwill \& K. Balkwill (Moyo et al., 2008), and tropical and coniferous trees (Bashalkhanov and Rajora, 2008). According to Friar (2005), the presence of polyphenols in DNA solutions inhibits the activity of enzymes that are used in molecular biology experiments, such as DNA ligases, polymerases and endonucleases, and therefore affects analyses that require the use of PCR.

The time and cost associated with DNA extraction are important aspects that must be considered. In general, it is a laborious process that is difficult to automate while ensuring optimal results in terms of quality and quantity (Friar, 2005). Several types of commercial DNA extraction kits are available on the market. Most are based on the use of relatively costly columns and yield the same results as much less expensive cetyltrimethylammonium bromide (CTAB) methods (Smith et al., 2005). Both commercial kits and the CTAB method modified for phenol extraction (CIMMYT, 2005) involve many stages that are highly time consuming, which makes them less feasible for researchers who must conduct many extractions.
This article describes a simple and robust protocol for DNA isolation in species with high phenolic compound contents and allows researchers to obtain highly pure, high-quality material that can be used in digestion assays with restriction enzymes and in high-productivity PCR amplification methods. The method is based on the activated charcoal-CTAB protocol described by Krizman et al. (2006) with modifications. While testing this method, we found two limitations: the low content of the DNA obtained, which makes it impractical to performed large-scale genotyping (Krizman et al. 2006), and the low quality of the DNA obtained, which affects the digestion or amplification of the DNA. The effectiveness of the method proposed here for extracting large amounts of DNA from leaves with high phenolictype secondary metabolite content was tested on leaves from potato and maize landraces cultivated in vitro and through seed germination in the laboratory. The results of this method are compared with a commercial genomic DNA extraction kit and three common protocols developed for the DNA extraction from Agavaceae (Keb-Llanes et al., 2002), the extraction of DNA from plants with high polyphenol content (Fulton et al., 1995), which was developed for Solanaceae, and the Krizman et al. (2006) method.

\section{Materials and methods}

In the present study, we used leaves of three plant genotypes of $S$. tuberosum sp tuberosum and $Z$. mays, which are local varieties cultivated in Chile. All of them form part of the germplasm collection of the Instituto de Investigaciones Agropecuarias (INIA-Chile). Leaves from each potato genotype were obtained from plants subcultured on MS medium (Murashige and Skoog, 1962) containing sucrose (3\%), pH 5.6 \pm 1 , and solidified with agar ( $8 \mathrm{~g})$. The cultivation conditions were $23 \pm 2{ }^{\circ} \mathrm{C}$ and a 16:8 light:darkness photoperiod. In maize, young leaves were obtained from seeds that were germinated in a growing chamber. Seeds were germinated using rolled paper in accordance with 
ISTA standards (International Seed Testing Association, http://www.seedtest.org/en/home.html).

Extraction buffer: For $100 \mathrm{~mL}$, mix $10 \mathrm{~mL}$ of 100 $\mathrm{mM}$ Tris- $\mathrm{HCl}(\mathrm{pH} 8.0), 40 \mathrm{~mL}$ of $2 \mathrm{M} \mathrm{NaCl}, 4$ $\mathrm{mL}$ of $20 \mathrm{mM}$ EDTA (pH 8.0) and $2 \% \mathrm{w} / \mathrm{v}$ CTAB (AppliChem, Darmstadt, Germany), which should have been previously dissolved in distilled water $(20 \mathrm{~mL})$ and heated in a thermal bath at $55{ }^{\circ} \mathrm{C}$ for $5 \mathrm{~min}$. Bring this solution to its final volume with sterile distilled water. This stock mixture can be kept at room temperature for long periods. Prior to use, add $1 \% \mathrm{w} / \mathrm{v}$ of polyvinylpyrrolidone (PVP) K40 PM: 40.000 (AppliChem, Darmstadt, Germany) and $0.5 \% \mathrm{w} / \mathrm{v}$ of activated charcoal (Merck, Darmstadt, Germany). Shake the buffer well before using. Use the extraction buffer within three days. Before preparing the extraction buffer, estimate the volume of stock mixture needed for the number of tissue samples that are to be extracted. For best results, the reagents must be of high purity.

DNA extraction procedure: (i) Collect 50-100 $\mathrm{mg}$ of vegetable tissue in a $1.5 \mathrm{~mL}$ centrifuge microtube. Cool the tissue in liquid nitrogen, and grind with a plastic pestle. (ii) Add $500 \mu \mathrm{L}$ of extraction buffer and mix by gentle inversion to homogenize the tissue with the buffer. Incubate the homogenate at $55{ }^{\circ} \mathrm{C}$ for $20 \mathrm{~min}$. Centrifuge the homogenate at $12,000 \mathrm{rpm}$ at room temperature for $5 \mathrm{~min}$. (iii) With a $200 \mu \mathrm{L}$ micropipette, carefully pipette the aqueous phase and transfer it to a new microtube. Add 1 volume of chloroform:isoamyl alcohol (24:1), and mix the sample gently with continuous rocking for $1 \mathrm{~min}$. Centrifuge the sample at $12,000 \mathrm{rpm}$ at room temperature for $5 \mathrm{~min}$. The following is an optional step: cleaner DNA but with lower yield can be obtained by repeating the chloroform:isoamyl alcohol treatment on the aqueous phase. (iv) Place the supernatant in a new microtube, and add one volume of ice-cold isopropanol. Mix the sample gently 2-3 times to precipitate the nucleic acid, and let it settle at $-20{ }^{\circ} \mathrm{C}$ for $30 \mathrm{~min}$. Centrifuge the sample at $12,000 \mathrm{rpm}$ at room temperature for
5 min to form a pellet at the bottom of the tube. (v) Discard the supernatant, and clean the pellet with $300 \mathrm{~mL} \mathrm{75 \%}$ ethanol. Shake the tube using a vortex shaker for $1 \mathrm{~min}$ to wash the pellet. Spin the tube for $1 \mathrm{~min}$, and discard the ethanol. The following is an optional step: for a cleaner pellet, repeat the ethanol wash. (vi) Dry the pellet by inverting the microtube onto a paper towel and letting it sit for 30 min until the ethanol evaporates completely or by placing it in a drying chamber for $15 \mathrm{~min}$. Suspend the DNA in $50 \mu \mathrm{L}$ of TE buffer (10 mM Tris-HCl, pH 8.0, 1 mM EDTA) or double-distilled water. Add $1 \mu \mathrm{L}$ of RNAse A (Epicentre, $5 \mu \mathrm{g} \mu \mathrm{L}^{-1}$ ) to each sample. Store the DNA solution at $4{ }^{\circ} \mathrm{C}$ until use. If the DNA will not be used for a long time, store it at $-20^{\circ} \mathrm{C}$. Optional step: For cleaner DNA, RNAse can be added to the supernatant and incubated at $37^{\circ} \mathrm{C}$ for $20 \mathrm{~min}$ before the ice-cold isopropanol step.

Other DNA extraction protocols. The methods described by Keb-Llanes et al. (2002), Fulton et al. (1995) and Krizman et al. (2006) and the commercial kit AxyPrep Multisource Genomic DNA Miniprep (Axygen, Union City, CA, USA) were used as controls for comparison with the proposed modified extraction method. When not included in the original protocols, $1 \mu \mathrm{L}$ of RNase A was added in the re-suspending step.

Quantity and visual quality of DNA obtained. The DNA obtained was visualized by electrophoresis on $1 \%$ agarose gels containing ethidium bromide. UV light was used to expose the bands. To determine the amount of DNA obtained, absorbance was measured by spectrophotometry utilizing the ACTGene (ASP-2680) with an absorbance ratio of A260/A280 nm. The quality of the DNA obtained was evaluated as a function of its digestion by endonucleases and its amplification by PCR.

\section{DNA quality for molecular biology assays}

The restriction enzyme EcoRI (100,000 units $\mathrm{mL}^{-1}$, New England Biolabs) was used to evalu- 
ate digestibility. The protocol for digestion was performed in accordance with the manufacturer's instructions. In a final volume of $20 \mu \mathrm{L}, 16 \mu \mathrm{L}$ of nuclease-free water was mixed with $2 \mu \mathrm{L}$ of $10 \mathrm{X}$ EcoRI buffer (50 mM Tris- $\mathrm{HCl}$ (pH 7.5), $10 \mathrm{mM}$ $\mathrm{MgCl}_{2}, 100 \mathrm{mM} \mathrm{NaCl}, 0.02 \%$ Triton X-100, 0.1 $\left.\mathrm{mg} \mathrm{mL}{ }^{-1} \mathrm{BSA}\right), 1 \mu \mathrm{L}$ of genomic DNA $(0.5-1 \mu \mathrm{g}$ $\left.\mu \mathrm{L}^{-1}\right)$ and 0.5 units of EcoRI enzyme, and it was incubated at $37^{\circ} \mathrm{C}$ for $4 \mathrm{~h}$. The digested samples were then separated by electrophoresis using $1 \%$ agarose gels.

\section{PCR amplification and fragment analysis}

To evaluate the quality of the potato DNA and its suitability for PCR, the gene that encodes the $ß$-carotene hydroxylase enzyme was amplified. The primers BCH-F (5'CAT GAC ATA GTT TGA ATT TTG AGT C 3') and BCH-R (3'CGT TTG GCG CTG CCG TAA GTT 5') were used, which generate a 290 bp fragment. PCR was conducted utilizing the $10 \mathrm{X}$ buffer, with final concentrations of $4 \mathrm{mM}$ of $\mathrm{MgCl}_{2}, 150 \mu \mathrm{M}$ of a blend of each of the dNTPs, $1 \mu \mathrm{M}$ of each primer, $1.25 \mu \mathrm{L}$ of Taq (at a concentration of $5 \mathrm{U}_{\mu} \mathrm{L}^{-1}$ ) (\#EP0282 Fermentas, Inc.) and 20 ng of DNA. An XP cycler-A (Bioer, China) was used for thermal cycling as follows: $3 \mathrm{~min}$ at $94{ }^{\circ} \mathrm{C} ; 40$ cycles of $30 \mathrm{~s}$ at $94^{\circ} \mathrm{C}, 30 \mathrm{~s}$ at $58^{\circ} \mathrm{C}$ and $1 \mathrm{~min} 30 \mathrm{~s}$ at 72 ${ }^{\circ} \mathrm{C}$; and $5 \mathrm{~min}$ at $72{ }^{\circ} \mathrm{C}$.

To assess the quality of the maize DNA and its suitability for PCR, the microsatellite sequence (SSR) bnlg1070 was amplified (Smith et al., 1997; CIMMYT, 2005). PCR was conducted utilizing the $10 \mathrm{X}$ buffer, $2.5 \mathrm{mM}$ of $\mathrm{MgCl}_{2}, 150 \mu \mathrm{M}$ of a blend of each of the dNTPs, $0.25 \mu \mathrm{M}$ of each primer, 1 $\mathrm{U}$ of Taq (concentration of $5 \mathrm{U}_{\mu} \mathrm{L}^{-1}$ ) (Fermentas, Inc.) and 50 ng of DNA. The mixture was brought to a final volume of $15 \mu \mathrm{L}$ using ultrapure water. PCR was carried out using a "touchdown" program. An XP cycler-A (Bioer, China) was used for thermal cycling as follows: 1 cycle of $2 \mathrm{~min}$ at $94{ }^{\circ} \mathrm{C}$; a "touchdown" protocol composed of 7 cycles of $1 \mathrm{~min}$ at $94{ }^{\circ} \mathrm{C}$, hybridization at 65
${ }^{\circ} \mathrm{C}$ (for the first cycle) decreasing $1{ }^{\circ} \mathrm{C}$ per cycle to $61{ }^{\circ} \mathrm{C}$ in the last cycle and $2 \mathrm{~min}$ at $72{ }^{\circ} \mathrm{C} ; 30$ cycles of $20 \mathrm{~s}$ at $94{ }^{\circ} \mathrm{C}, 1 \mathrm{~min}$ at $60^{\circ} \mathrm{C}, 2 \mathrm{~min}$ at $72{ }^{\circ} \mathrm{C}$; and 1 cycle at $94{ }^{\circ} \mathrm{C}$ for $6 \mathrm{~min}$. Both products were visualized with a $1 \%$ agarose gel.

\section{Results and discussion}

There are many methods for isolating genomic DNA that involve both the selective precipitation and inactivation of contaminating substances. High concentrations of CTAB are used to remove polysaccharides in an initial extraction step or in a scaled manner, thus aiding in the selective precipitation of DNA. A high concentration of CTAB with PVP or polyvinylpolypyrrolidone (PVPP) helps to remove polyphenols. Some protocols use ascorbic acid, diethyldithiocarbamic acid (DIECA) and 2-mercaptoethanol to reduce oxidation and prevent the degradation of DNA (Fulton et al., 1995; Keb-Llanes et al., 2002; Hidenori, 2007). In this study, activated charcoal and PVP were used simultaneously. Both substances help with the removal of high levels of polyphenols during DNA extraction. These substances may have a synergistic effect by binding to the polyphenols (Friar, 2005). The presence of contaminants depends on the type of vegetable tissue and its state of development at the time of extraction. There are significant differences in the yield, purity, susceptibility to digestion with restriction enzymes and suitability of the DNA for PCR as a consequence of these factors (Porebski et al., 1997; Boiteux et al., 1999). Krizman et al. (2006) were of the opinion that among other factors, the amount of sample extracted could be critical in keeping an extraction procedure robust.

The DNA extraction methodology described here was equally efficient in extracting DNA from tissues of both potato and maize, allowing for the extraction of high-quality genomic DNA from both species. Our DNA protocol was more suitable for PCR-based molecular techniques compared with the other protocols tested (Figures 
1A, 1C, 2A and 2C). Our method was similar to the one proposed by Krizman et al. (2006), as both methods utilize activated charcoal and PVP, confirming the efficiency of activated charcoal (Bi et al., 1996) in combination with PVP to remove different polyphenolic compounds of different nature. However, better results were obtained with our modifications. The main difference between the two protocols was in the precipitation conditions and washing steps. In Krizman et al. (2006), DNA was precipitated with isopropanol under high-temperature conditions, and this likely affected the precipitation of short molecules of nucleic acid, reducing the final DNA yield. Additionally, a solution of ammonium acetate and ethanol was used in the washing step. The use of this salt in DNA precipitation or washing steps considerably affects the DNA yield (Miller et al., 1999).
Another advantages of our method is that it is less time consuming, similar to the commercial DNA extraction kit (Table 1), and although cheaper.

In potato and in comparison with the other methods, our protocol was suitable for both restriction enzyme digestion and PCR (Figures 1B and 1C). Using the Krizman et al. (2006) protocol, it was possible to obtain a good quantity of DNA but with low quality, which was reflected by the absence of a PCR product. Similar results were obtained with the protocols of Fulton et al. (1995) and Keb-Llanes et al. (2002), in which some PCR amplifications were unsuccessful.

In maize, the efficacy of our protocol was also greater. High-quality DNA was obtained in large quantities. In comparison with the other

Table 1. General description of the comparable parameters of the extraction methods.

\begin{tabular}{|c|c|c|c|c|c|c|}
\hline $\begin{array}{l}\text { Model } \\
\text { organism }\end{array}$ & $\begin{array}{c}\text { Method } \\
\text { (Reference) }\end{array}$ & Type of tissue & $\begin{array}{l}\text { Incubation } \\
\text { Conditions } \\
\text { (lysis) }\end{array}$ & $\begin{array}{c}\text { Concentration } \\
\left(\mathrm{ng} \mu \mathrm{L}^{-1}\right) \\
\text { (average of three } \\
\text { samples) } \\
\end{array}$ & $\begin{array}{l}\text { Ratio of } \\
260 / 280\end{array}$ & $\begin{array}{c}\text { Total Time } \\
\text { Required to } \\
\text { Process } 1 \\
\text { Sample (min) }{ }^{1}\end{array}$ \\
\hline \multirow{5}{*}{$\begin{array}{l}\text { Solanum } \\
\text { tuberosum }\end{array}$} & Fulton et al. (1995) & In vitro leaves & $\begin{array}{c}65^{\circ} \mathrm{C} \text { for } \\
30-120 \mathrm{~min}\end{array}$ & 742.6 & 2.60 & $145-150$ \\
\hline & Keb-Lanes et al., 2002 & In vitro leaves & $\begin{array}{l}65^{\circ} \mathrm{C} \text { for } \\
10 \mathrm{~min}\end{array}$ & 318.3 & 2.42 & $215-250$ \\
\hline & Our method & In vitro leaves & $\begin{array}{l}55^{\circ} \mathrm{C} \text { for } \\
20 \mathrm{~min}\end{array}$ & 417.8 & 2.09 & $82-97$ \\
\hline & Križman et al, 2006 & In vitro leaves & $\begin{array}{l}55^{\circ} \mathrm{C} \text { for } \\
30 \mathrm{~min}\end{array}$ & 233.1 & 2.57 & $140-150$ \\
\hline & $\begin{array}{l}\text { AxyPrep Multisource } \\
\text { Genomic DNA Kit }\end{array}$ & In vitro leaves & $\begin{array}{l}56^{\circ} \mathrm{C} \text { for } \\
10 \mathrm{~min}\end{array}$ & 52.3 & 1.18 & $52-60$ \\
\hline \multirow{5}{*}{ Zea mays } & Fulton et al., 1995 & Leaves & $\begin{array}{c}65^{\circ} \mathrm{C} \text { for } \\
30-120 \mathrm{~min}\end{array}$ & 552.3 & 2.43 & $145-150$ \\
\hline & Keb-Lanes et al., 2002 & Leaves & $\begin{array}{l}65^{\circ} \mathrm{C} \text { for } \\
10 \mathrm{~min}\end{array}$ & 127.2 & 2.34 & $215-250$ \\
\hline & Our method & Leaves & $\begin{array}{l}55^{\circ} \mathrm{C} \text { for } \\
20 \mathrm{~min}\end{array}$ & 1580.6 & 2.01 & $82-97$ \\
\hline & Križman et al, 2006 & Leaves & $\begin{array}{l}55^{\circ} \mathrm{C} \text { for } \\
30 \mathrm{~min}\end{array}$ & 423.33 & 2.42 & $140-150$ \\
\hline & $\begin{array}{l}\text { AxyPrep Multisource } \\
\text { Genomic DNA Kit }\end{array}$ & Leaves & $\begin{array}{l}56^{\circ} \mathrm{C} \text { for } \\
10 \mathrm{~min}\end{array}$ & 268.1 & 2.22 & $52-60$ \\
\hline
\end{tabular}

${ }^{1}$ Without grinding step. 

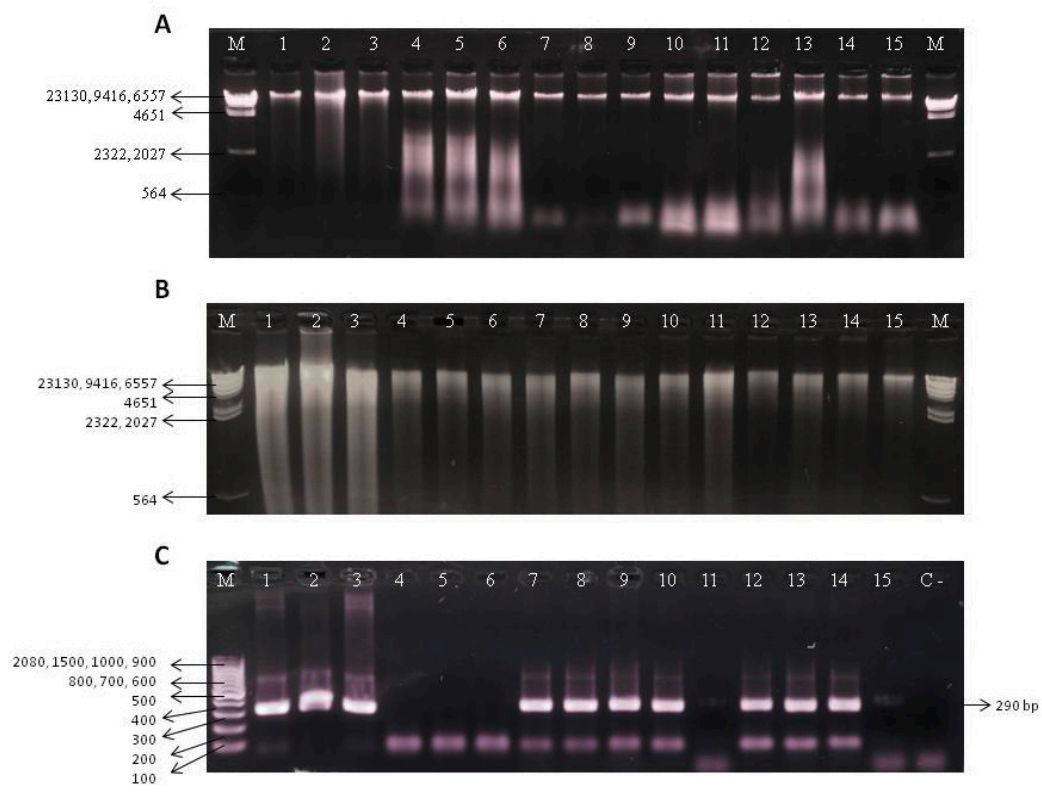

Figure 1. Lines 1-3: AXIGEN commercial kit, 4-6: Krizman protocol, 7-9: our protocol, 10-12: Fulton protocol, $13-$ 15: Keb-Llanes protocol. 1A. Electrophoresis of total DNA of Solanum tuberosum. $M=$ marker $\lambda$ DNA/HindIII. 1B. Evaluation of the quality of $S$. tuberosum genomic DNA extracted using digestion. $M=$ marker $\lambda$ DNA/HindIII. 1C. Evaluation of the quality of $S$. tuberosum DNA by PCR amplifying the gene encoding the $\beta$-carotene hydroxylase enzyme, generating a $290 \mathrm{bp}$ fragment. $\mathrm{M}=\mathrm{Gen}$ ruler $^{\mathrm{TM}} 100 \mathrm{bp}$ DNA ladder weight marker. A $1 \%$ agarose gel run at 70 volts for 40 min and stained using ethidium bromide.

methods, digestion with the restriction enzyme was complete, and PCR products were obtained from all of the samples.

DNA shows maximum absorbance at $260 \mathrm{~nm}$. Proteins, which are the most common impurities in DNA preparations, show maximum absorbance at $280 \mathrm{~nm}$. These wavelengths are used to verify the purity of DNA. If the ratio is between 1.7 and 2.0, the DNA preparation is considered to have a minimum amount of contaminants. A lower ratio suggests protein or phenolic impurities (Hollingsworth, 2006). Using optical density (OD) measurement at 260-280 nm, our methodology yielded $418 \mathrm{ng} \mu \mathrm{L}^{-1}$ of genomic DNA for each 50-100 mg of potato leaf tissue (Table 1). The concentrations were even higher from maize (1580 ng $\mu \mathrm{L}^{-1}$ ). Using our protocol in potato and maize, the absorbance ratios of the DNA samples were considerably improved compared with those of samples produced using the other protocols. This result suggests less secondary metabolites in the extract and therefore higher purity (Table 1).
Plant DNA, which is free of inhibitory metabolites, is a better template to amplify PCR products (Miller et al. 1999). In potato, we used the BCH-F (5'CAT GAC ATA GTT TGA ATT TTG AGT C 3') and BCH-R (3'CGT TTG GCG CTG CCG TAA GTT $\left.5^{\prime}\right)$ primers. Our protocol enabled the amplification of a $290 \mathrm{bp}$ fragment from all samples, which was identical to that observed with the use of the commercial kit (Figure 1C). In maize, quality was evaluated through amplification with the bnlg1070 SSR primer. The marker was amplified using DNA extracted by either the commercial kit or and our method, so the cheapest method should be used.

Finally, for both species, the DNA was completely digested using the EcoRI restriction enzyme, and $1 \mu \mathrm{g}$ of the DNA was obtained (Figures $1 \mathrm{~B}$ and 2B). Using this methodology, we demonstrated the stability of the DNA for use in molecular biology techniques.

In conclusion, when both DNA yield and purity were considered, our procedure was deemed 
to be superior to the other methods tested. Our method allows for the efficient molecular analysis, including PCR and restriction enzyme digestion, of DNA samples from potato and maize tissues. The described protocol is fast $(\sim 1.5 \mathrm{~h})$ and simple, allowing for the extraction of several samples in a single day. It can also be performed at a lower cost compared with the other protocols tested, making it ideal for large-scale genotyping analysis.

\section{Acknowledgments}

The authors of this article would like to acknowledge INIA- Remehue and INIA-La Platina Regional Research Center and specially to La Platina Biotechnology and Genetic Resources Laboratories, which provided the plant material and infrastructure to conduct this research.

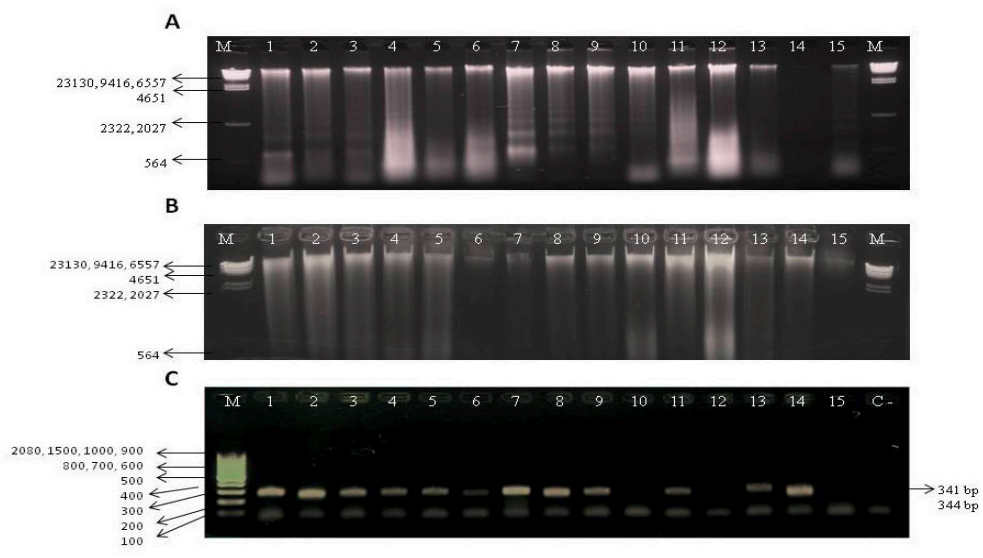

Figure 2. Lines 1-3: AXIGEN commercial kit, 4-6: Križman protocol, 7-9: our protocol, 10-12: Fulton protocol, 13-15: Keb-Llanes protocol. 2A. Electrophoresis of total DNA of Zea mays. $\mathrm{M}=$ marker $\lambda$ DNA/HindIII. $2 \mathrm{~B}$. Evaluation of the quality of Zea mays genomic DNA extracted using digestion. $\mathrm{M}=$ marker $\lambda$ DNA/HindIII. 2C. Evaluation of the quality of $Z$. mays DNA by PCR, amplifying SSR bnlg1070. $\mathrm{M}=\mathrm{Gen}$ ruler $^{\mathrm{TM}} 100 \mathrm{bp}$ DNA ladder weight marker. A $1 \%$ agarose gel run at 70 volts for $40 \mathrm{~min}$ and stained using ethidium bromide.

\section{Resumen}

M. Barra, E. Salazar, M. Beltrán y B. Sagredo. 2012. Método simple y robusto de extracción de ADN para análisis a gran escala de genotipos con alto contenido de polifenoles, como son variedades nativas de Solanum tuberosum and Zea mays. Cien Inv. Agr. 39(3): 593-601. La extracción de ADN de alta calidad es esencial para realizar estudios a nivel molecular, en diversas especies con abundancia de polifenoles en sus tejidos, como ocurren en las variedades tradicionales de papa y maíz, que dificultan una buena extracción de ADN genómico. Los polifenoles interfieren en la amplificación del ADN durante la reacción en cadena de la polimerasa (PCR), lo que dificulta realizar estudios de marcadores moleculares basados en PCR. Este artículo describe un protocolo simple y robusto de aislamiento de ADN aplicado a variedades tradicionales de papa y maíz obteniéndose una concentración alta, de gran pureza y calidad. El método desarrollado se basa en el de Krizman et al. (2006), con modificaciones, 
probándose en hojas de papa y hojas jóvenes de maíz. El método propuesto se comparó con un kit comercial de extracción de ADN y tres métodos descritos para extracción de ADN de plantas: uno descrito para plantas con altos contenidos de polifenoles (Keb-Llanes et al., 2002), un segundo descrito para Solanaceas y otras planta herbáceas (Fulton et al., 1995), y el método de Krizman et al. (2006) original basado en el uso de bromuro de cetyltrimethylammonio (CTAB)-y carbón activado. Mediante este método es posible aislar ADN desde genotipos de papa y maíz, con altos contenidos de polifenoles, y obtener ADN de alta calidad que puede ser utilizado para su uso en técnicas moleculares que involucren la reacción de PCR y el corte con enzimas de restricción. El método es de corta duración, similar a la del kit comercial, pero de menor costo. La cantidad de ADN de maíz extraído es superior al utilizar el método propuesto, en comparación con los otros métodos probados.

Palabras clave: Carbón activado, DNA genómico, extracción de DNA, polifenoles.

\section{References}

Bashalkhanov, S., and O. Rajora. 2008. Protocol: A high-throughput DNA extraction system suitable for conifers. Plant Methods 4:20.

Bennett, R.N., and R.M. Wallsgrove. 1994. Secondary metabolites in plant defence mechanisms. New Phytologist 127:617-633.

Bi, I.V., L. Harvengt, A. Chandelier,G. Mergeai, P. Du Jardin. 1996. Improved RAPD amplification of recalcitrant plant DNA by the use of activated charcoal during DNA extraction. Plant Breeding 115:205-206.

Boiteux, L.S., M.E.N. Fonseca, and P.W. Simon. 1999. Effects of plant tissue and DNA purification method on randomly amplified polymorphic DNA-based genetic fingerprinting analysis in Carrot. Journal of the American Society for Horticultural Science 124:32-38.

CIMMYT. 2005. Laboratory Protocols. CIMMYT Applied Molecular Genetics Laboratory. Third Edition. Mexico. D.F. 102 pp.

Friar E, A. 2005. Isolation of DNA from plants with large amounts of secondary metabolites methods in enzymology. Methods Enzymol. 395:3-14.

Fulton, T., J. Chunwongse, and S. Tanksley. 1995. Microprep protocol for extraction of DNA from tomato and other herbaceous plants. Plant Molecular Biology Reporter 13:207-209.
Hidenori, S. 2007. A technique to isolate DNA from woody and herbaceous plants by using a silicabased plasmid extraction column. Anal. Biochem. 363.166-167.

Hollingsworth, M. 2006. DNA fingerprinting in plants: principles, methods, and applications. Annals of Botany 97:476-477.

Huamán, Z., and D.M. Spooner. 2002. Reclassification of landrace populations of cultivated potatoes (Solanum sect. Petota). American Journal of Botany 89:947-965.

Keb-Llanes, M., G. González, B. Chi-Manzanero, D. Infante. 2002. A rapid and simple method for small-scale DNA extraction in Agavaceae and other tropical plants. Plant Molecular Biology Reporter 20:299-299.

Križman, M., J. Jakše, D. Baričevič, B. Javornik, and P. Mirko. 2006. Robust CTAB-activated charcoal protocol for plant DNA extraction. Acta Agriculturae Slovenica 87:427-433.

Miller, D.N., J.E. Bryant, E.L. Madsen, and W.C. Ghiorse. 1999. Evaluation and Optimization of DNA Extraction and Purification Procedures for Soil and Sediment Samples. Appl. Environ. Microb. 65.4715-4724.

Moyo, M., S.O. Amoo, M.W. Bairu, J.F. Finnie, V.S.J. Optimising. 2008. DNA isolation for medicinal plants. South African Journal of Botany 4:771-775. 
Mullins, E., D. Milbourne, C. Petti, B.M. DoylePrestwich, and C. Meade. 2006. Potato in the age of biotechnology. Trends in Plant Science 11:254-260.

Murashige, T. and F. Skoog. 1962. A revised medium for rapid growth and bioassays with tobacco tissue cultures. Physiol. Plantarum 15:473-497.

Porebski, S., L. Bailey, and B. Baum. 1997. Modification of a CTAB DNA extraction protocol for plants containing high polysaccharide and polyphenol components. Plant Molecular Biology Reporter 15:8-15.

Ranilla, L.G., E. Apostolidis, M.I. Genovese, F.M. Lajolo, and K. Shetty. 2009. Evaluation of indigenous grains from the Peruvian Andean Region for antidiabetes and antihypertension potential using in vitro methods. Journal of Medicinal Food 12:704-713.
Ranilla, L.G., M.I. Genovese, and F.M. Lajolo. 2006. Polyphenols and antioxidant capacity of seed coat and cotyledon from Brazilian and Peruvian bean cultivars (Phaseolus vulgaris L.). J. Agr. Food Chem. 55:90-98.

Smith, D.S., P.W. Maxwell, and S.H. De Boer. 2005. Comparison of several methods for the extraction of DNA from potatoes and potato-derived products. J. Agr. Food Chem. 53:9848-9859.

Smith, J.S.C., E.C.L. Chin, H. Shu, O.S. Smith, S.J. Wall, M.L. Senior, S.E. Mitchell, S. Kresovich, and J. Ziegle. 1997. An evaluation of the utility of SSR loci as molecular markers in maize (Zea mays L.): comparisons with data from RFLPS and pedigree. TAG Theoretical and Applied Genetics 95:163-173. 
